\section{COMPARISON OF PARTICLE SWARM OPTIMIZATION AND Response SuRfaCe Methodology IN FERMENTATION MEDIA OPtIMIZATION OF FleXIRUBIN PRODUCTION}

Siti Nurulasilah Suhaimia, Siti Mariyam Shamsuddina*, Wan Azlina Ahmadb, Shafaatunnur Hasana, Chidambaram Kulandaisamy Venilb

aSchool of Computing, Faculty of Engineering, Universiti Teknologi Malaysia, 81310 UTM Johor Bahru, Johor, Malaysia bDepartment of Chemistry, Faculty of Science, Universiti Teknologi Malaysia, 81310 UTM Johor Bahru, Johor, Malaysia
Article history

Received

11 December 2017

Received in revised form

12 November 2018

Accepted

1 December 2018

Published online

18 February 2019

*Corresponding author mariyam@utm.my

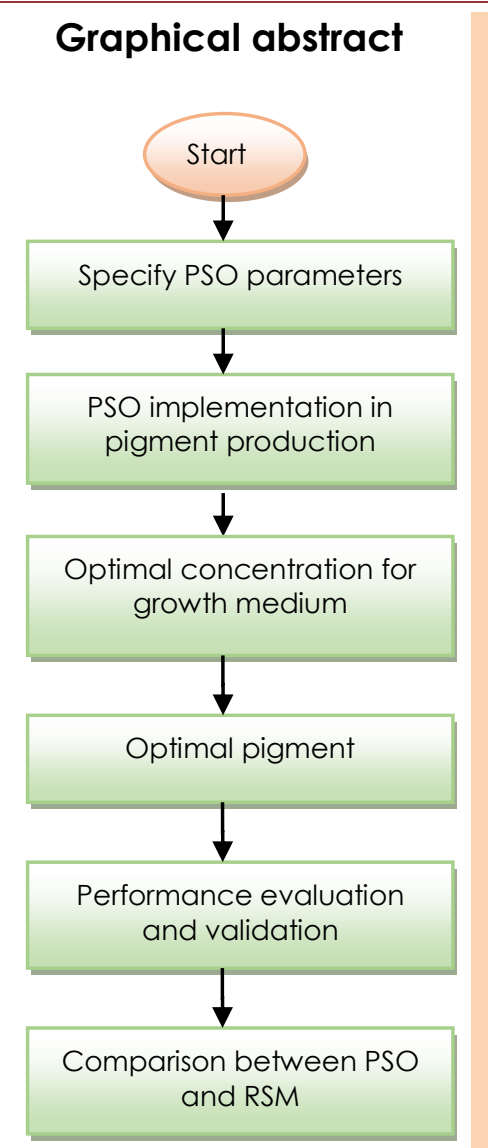

\begin{abstract}
At present, response surface methodology (RSM) is the most preferred method for fermentation media optimization. However, in the last two decades, artificial intelligence algorithm has become one of the most efficient methods for empirical modelling and optimization. One of the popular developed approaches is Particle Swarm Optimization (PSO), which is used in optimizing a problem. This paper focuses on comparative studies between RSM and PSO in fermentation media optimization for the production of flexirubin production using Chryseobacterium artocarpi CECT 8497T. Two methodologies were compared-for in terms of their modeling, sensitivity analysis, and optimization abilities. All experiments were performed accordingly to box-behnken design (BBD), and the generated data was analyzed using RSM and PSO. The sensitivity analysis performed by both methods has given comparative results. Based on the correlation coefficient, the model developed with PSO was found to be superior to the model developed with RSM. The result shows that PSO gives a better pigmentation yield with optimal fermentation concentration.
\end{abstract}

Keywords: Optimization, response surface methodology, particle swarm optimization, flexirubin

\title{
Abstrak
}

Pasa masa kini, metodologi permukaan tindak balas (RSM) adalah kaedah yang paling digunakan bagi pengoptimuman media penapain setakat ini. Walau bagaimanapun, dalam dua dekad yang lalu, algoritma kecerdasan buatan telah muncul sebagai salah satu kaedah yang paling berkesan untuk model empirikal dan pengoptimuman, salah satu kaedah popular adalah Particle Swarm Optimization (PSO), yang digunakan dalam mengoptimumkan masalah. Kajian ini memberi tumpuan kepada perbandingan antara RSM dan PSO dalam pengoptimuman media penapaian dalam pengeluaran flexirubin menggunakan Chryseobacterium artocarpi CECT 8497T. Dua metodologi ini telah dibandingkan dengan pemodelan, analisis kepekaan dan keupayaan pengoptimuman. Semua percubaan telah dilakukan dengan sewajarnya mengikut reka bentuk kotakbehnken (BBD) dan data yang dihasilkan dianalisis menggunakan RSM dan PSO. Analisis sensitiviti yang dilakukan oleh kedua-dua kaedah telah memberikan hasil perbandingan. Berdasarkan pekali korelasi, model yang dibangunkan dengan PSO didapati lebih unggul berbanding model yang dibangunkan dengan RSM. Hasilnya menunjukkan PSO memberikan hasil pigmentasi yang lebih baik dengan kepekatan penapaian optimum.

Kata kunci: Pengoptimuman, kaedah gerak balas permukaan, particle swarm optimization, kecerdasan buatan, sisa pertanian

(C) 2019 Penerbit UTM Press. All rights reserved 


\subsection{INTRODUCTION}

Nowadays, synthetic pigment has been banned, or is being banned as it poses a hazard to human health and the environment [1]. Due to the toxicological problem of synthetic pigment, the demand for natural pigment has increased. This has resulted in the scientific community's increased interest towards natural colours [2, 3]. However, producing quality natural pigments is hampered by the high cost of the pigment growth medium. Therefore, various studies have been done to explore other medium, which are cheaper such as agricultural materials. Furthermore, the use of these residues is ecologically safe, minimizes hazardous chemicals, and also helps to reduce its environmental impact.

Among the natural sources, microbes are gaining increased attention due to their broad ranging activities: short life cycle, highly versatile, faster fermentation, simple propagation techniques, easy downstream processing and structural complexity, which make them suitable for industrial needs [4]. In this study, a bacteria strain called Chryseobacterium artocarpi collected from agricultural waste residue has been used to produce a bacteria pigment called flexirubin. This study focuses on finding the optimal concentration of growth medium for flexirubin production.

The development of proper fermentation media is a necessary and important step in efficient utilization fermentation technology [5]. The pigment productions of the bacteria are strongly influenced by their medium composition. Therefore, it needs suitable medium growth for optimum production of pigmentation. The use of different growth media directly affects the growth and production of the pigments.

However, the fermentation processes have multivariables factors and optimization of these medium components is a crucial task. In many reports, the limits of the classical method, which is one factor at a time (OFAT), have been discussed. Due to the complex interaction among the variable factors, these conventional methods (OFAT) are time consuming, and often incapable of reaching the true optimum [35]. To overcome this inability, two alternative approaches are commonly employed for media optimization: (1) statistical technique and (2) artificial intelligence (Al) technique.

In statistical based technique, response surface methodology (RSM) has been used extensively in fermentation media optimization [40]. RSM is based on design of experiments (DOE) for the development of models, estimation of the model coefficient, and the prediction of response for optimum conditions $[36,37]$. RSM estimates the relationship between the variable parameters (medium components), and response (product yield), where it adjusts the concentration of multi-variables to achieve the optimum concentration of the response (flexirubin production). However, RSM has some limitations. In the case of a large number of variables, the interaction between the factor variables and the response will increase the complexity of the study, and the feasibility of the method will be challenged [38]. In addition, the RSM fails to precisely describe an objective function [35, 39].

Due to the drawbacks of RSM, various optimization algorithms have been presented over the past few decades, and have continually improved in efficiency [6]. One of the optimization algorithms is Particle Swarm Optimization, where PSO has many advantages over other optimization such as generally easy to program. PSO also offers a more attractive choice to optimize non-linear and noncontinuous problems with multi-variables $[7,8]$. Particle swarm optimization (PSO) was introduced by Kennedy and Eberhart $[9,10,11]$, involved simulating behaviours such as bird flocking to find the most optimal results. PSO has been applied in numerous optimization and search problems, and it can be verified in many literature such as in task scheduling $[12,13]$, medical $[14,15]$, oil and gas $[16,17]$, batik production [18], and others. PSO also has been successfully implemented in modelling a large number of biochemical processes because it uses fewer control parameters, its ease of implementation, and ability to solve highly optimization problems $[19,20]$.

Due to the robustness, higher convergence rates in lesser computational time and flexibility of PSO approaches in optimizing complex problems, this study was intended to evaluate the computational effectiveness of PSO for the optimization of flexirubin production. The predictive ability of the statistical approach (RSM) and PSO were compared using dataset of 17 experiments. The predictive optimization abilities and sensitivity analysis of PSO were used to validate the results, and the authenticity was proven by the wet laboratory experiments.

The experimental findings revealed that using PSO based approach achieved high accuracy and correlation, which indicate that the results performed practically well. The findings should make an important contribution to the field of pigment production.

\subsection{METHODOLOGY}

\subsection{Experimental Setup and Design}

This study highlights the production of pigment (flexirubin) by bacteria strain Chryseobacterium artocarpi in agricultural waste material. Bacterial strain Chryseobacterium artocarpi CECT 8497' (=KCTC 32509') used in the present study was isolated from an orchard at Universiti Teknologi Malaysia (UTM), Skudai, Malaysia [21]. This strain produces 
yellowish-orange pigment, and it has been characterized and identified as flexirubin [21]. C. artocarpi CECT 8497 was cultivated in $100 \mathrm{~mL}$ Erlenmeyer flask containing $20 \mathrm{~mL}$ of nutrient broth $(\mathrm{NB})$, and incubated at $30^{\circ} \mathrm{C}$. The flask was incubated at $30^{\circ} \mathrm{C}$ with a shaking speed of $200 \mathrm{rpm}$ for 24 hours. The remaining sample was extracted and quantified for pigment yield as described by Venil et al. [21].

The experimental design for each independent variable is given in Table 1. Box-Behnken Design (BBD) was used to optimize response of the independent variables on flexirubin production (response). The coded values of each independent variable are given in Table 1. Three independent variables, Lactose $\left(x_{1}\right)$,

tryptophan $\left(x_{2}\right)$ and $\mathrm{KH}_{2} \mathrm{PO}_{4}\left(x_{3}\right)$ have been randomized according to Box-Behnken design, where the design contains 17 experiment trials as shown in Table 2.

Table 1 Independent variables and experimental design levels

\begin{tabular}{|c|c|c|c|c|}
\hline \multirow{2}{*}{$\begin{array}{l}\text { Independent } \\
\text { variables }\end{array}$} & \multirow{2}{*}{ Symbol } & \multicolumn{3}{|c|}{$\begin{array}{c}\text { Actual levels of code } \\
\text { factors }\end{array}$} \\
\hline & & -1 & 0 & +1 \\
\hline Lactose (mg/L) & $X_{1}$ & 10 & 11.25 & 12.5 \\
\hline $\begin{array}{l}\text { L-tryptophan } \\
\text { (mg/L) }\end{array}$ & $X_{2}$ & 4 & 6.5 & 8 \\
\hline $\mathrm{KH}_{2} \mathrm{PO}_{4}(p p m)$ & $X_{3}$ & 300 & 700 & 1000 \\
\hline
\end{tabular}

Table 2 Experimental and predicted values (RSM)

\begin{tabular}{llllll}
\hline No & \multicolumn{2}{l}{ Factors } & & $\begin{array}{l}\text { Experimental } \\
\text { (mg/L) }\end{array}$ & $\begin{array}{l}\text { RSM } \\
(\mathbf{m g} / \mathbf{L})\end{array}$ \\
\hline 1 & +1 & 0 & +1 & 172.22 & 169.24 \\
2 & -1 & -1 & 0 & 212.98 & 224.10 \\
3 & 0 & -1 & +1 & 350.18 & 327.19 \\
4 & 0 & 0 & 0 & 480.51 & 478.14 \\
5 & 0 & -1 & -1 & 378.40 & 333.29 \\
6 & 0 & 0 & 0 & 501.48 & 498.15 \\
7 & +1 & -1 & 0 & 203.46 & 198.47 \\
8 & 0 & 0 & 0 & 483.98 & 490.43 \\
9 & -1 & 0 & -1 & 199.12 & 209.05 \\
10 & +1 & +1 & 0 & 170.39 & 181.47 \\
11 & +1 & 0 & -1 & 249.21 & 255.42 \\
12 & -1 & 0 & +1 & 151.53 & 162.63 \\
13 & 0 & 0 & 0 & 472.51 & 467.42 \\
14 & 0 & +1 & -1 & 297.54 & 280.51 \\
15 & 0 & 0 & 0 & 483.11 & 491.30 \\
16 & -1 & +1 & 0 & 194.20 & 197.02 \\
17 & 0 & +1 & +1 & 252.95 & 268.41 \\
\hline
\end{tabular}

Figure 1 shows a schematic representation of this study. The objective of using particle swarm optimization is to determine the optimal concentration of medium parameters.

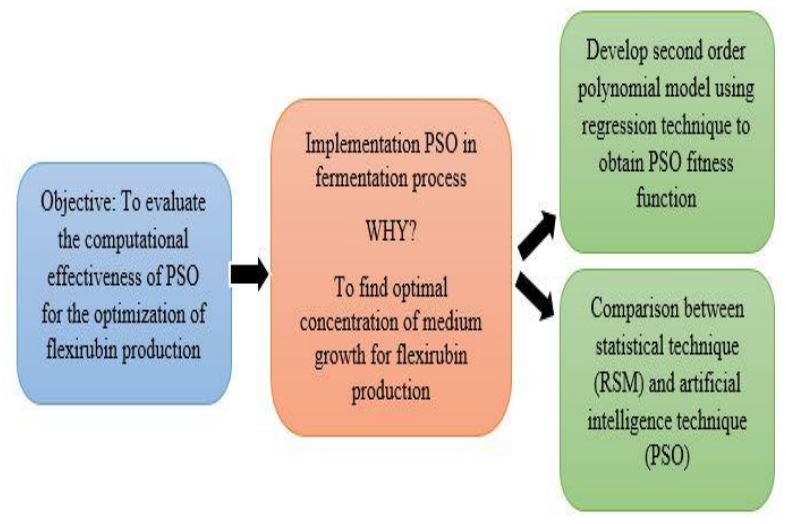

Figure 1 Schematic representation of the study

\subsection{Modelling and Optimization of Medium for Pigment Production}

\subsubsection{Response Surface Methodology}

RSM which includes factorial design and regression analysis is a statistical method for designing experiments, building models, evaluating the effect of factors, and searching for optimum conditions of factors for desirable response [9]. RSM surface model are multi-variables models, used to determine a set of variables that optimize a response (flexirubin production in this study).

Three medium variables which are $x_{1}, x_{2}$ and $x_{3}$ were selected to generate the model for flexirubin optimization. BBD was used to study the interaction effect between the independent variables, and optimize the medium of the flexirubin production. A three-level-factor BBD was employed to generate 17 experiment runs by considering three independent values, Lactose, L-tryptophan, and $\mathrm{KH}_{2} \mathrm{PO}_{4}$ as shown in Table 2. A mathematical model, describing the relationship between the dependent variable and independent variables (lactose, L-tryptophan, and $\mathrm{KH}_{2} \mathrm{PO}_{4}$ ) in a second-order polynomial model was developed accordingly as given in Equation (8).

$$
Y=\alpha_{0}+\sum_{j=1}^{k} \alpha_{j} X_{j}+\sum_{j=1}^{k} \alpha_{i j} X_{j}^{2}+\sum \sum \alpha_{i j} X_{i} X_{j}
$$

where $Y$ is the predicted response, $X_{i}$ and $X_{j}$ are coded as independent variables, while $\alpha_{0}, \alpha_{j}, \alpha_{i j}, \alpha_{i j}$ are the regression coefficient for the intercept, linear, quadratic and interaction effect, respectively,

By transferring the coefficient value of independent variable (see Table 3) into Equation (8), the final equation based on a second order polynomial with the optimized coefficient is given in Equation (9): 


$$
\begin{aligned}
& y=-17526.123+3017.057 x_{1}+(248.975) x_{2}+(1038.58) x_{3} \\
& +(-133.059) x_{1}^{2}+(-20.289) x_{2}^{2}+(-680.767) x_{3}^{2}+ \\
& (-1.429) x_{1} x_{2}+(-16.800) x_{1} x_{3}+(-5.846) x_{2} x_{3}
\end{aligned}
$$

where $y$ is yield (flexirubin production), $x_{1}, x_{2}$ and $x_{3}$ represent lactose, L-tryptophan and $\mathrm{KH}_{2} \mathrm{PO}_{4}$, respectively.

Significance was determined by examining the Pvalue, the smaller the P-value, the more significant the corresponding coefficient. Model P-value less than 0.05 shows that the model was significant to navigate the experimental data. Among the test variables used in the study, $X_{1}, X_{2}, X_{3}, X_{1}^{2}, X_{2}^{2}, X_{3}^{2}$ are significant model terms. The coefficient and corresponding P-value verified that the independent variables $X_{1}$ (lactose), $X_{2}$ (L-tryptophan) and $X_{3}$ $\left(\mathrm{KH}_{2} \mathrm{PO}_{4}\right)$ are significant model terms.

Table 3 Multiple linear regression analysis of the interaction between variables

\begin{tabular}{lllc}
\hline Parameter & Coefficient & t-value & P-value \\
\hline Constant & -17526.128 & -16.968 & $<0.05$ \\
$X_{1}$ & 3017.057 & 17.334 & 0.000 \\
$X_{2}$ & 248.975 & 3.755 & 0.007 \\
$X_{3}$ & 1038.580 & 2.940 & 0.022 \\
$X_{1}^{2}$ & -133.059 & -17.559 & 0.000 \\
$X_{2}^{2}$ & -20.289 & -6.854 & 0.000 \\
$X_{3}{ }^{2}$ & -680.707 & -7.043 & 0.000 \\
$X_{1} X_{2}$ & -1.429 & -0.294 & 0.777 \\
$X_{1} X_{3}$ & -16.800 & -0.605 & 0.564 \\
$X_{2} X_{3}$ & -5.846 & -0.337 & 0.746 \\
\hline
\end{tabular}

The fit model was also expressed with the correlation coefficient $R^{2}$, which was used as a tool to check the model, and was considered to be a perfect fit when the value was near to unity. As shown in Figure 2, $R^{2}$ was discovered to be approximately 0.985 indicating that $98.50 \%$ of the variability in the response could be clarified by the model. The laboratory analysis, together with statistical tests revealed that second-order polynomial equation was being utilized as the objective function, and particle swarm optimization was used to optimize the function.

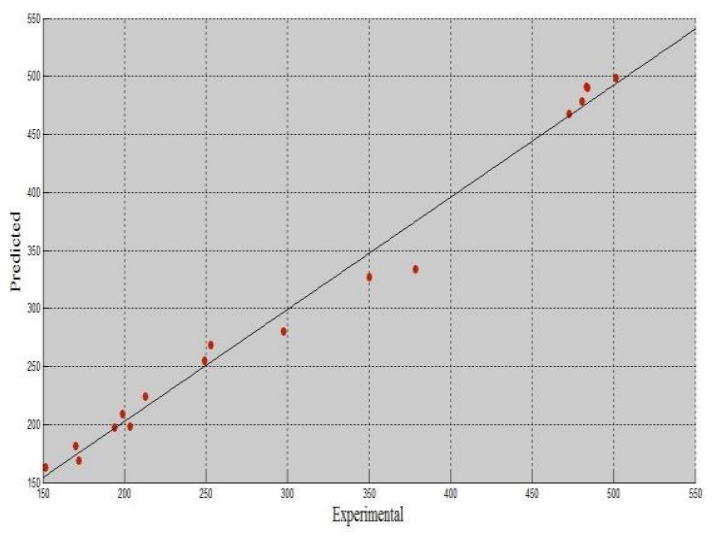

Figure 2 Experimental vs. predicted PSO

\subsubsection{Particle Swarm Optimization}

Particle Swarm Optimization (PSO) heuristic, as proposed by Eberhart and Kenedy, has been popular since 1995 [10,34]. It was inspired by nature, the flocking and swarm behaviour of birds, and also insects. Swarm intelligence algorithms are capable of handling local optima problems encountered in traditional gradient-based optimization technique (such as RSM), and are considered as one of the major enumerative techniques in operation search [22]. Their simplicity, robustness, and higher convergence rates in lesser computational time account for their popularity in solving complex, nonlinear problems [23, 24]. These algorithms differ from traditional, and gradient-based approaches in searching a population of points in parallel and not just a single point, and utilization of probabilistic transition rules instead of deterministic ones [24]. In this context, swarm intelligence-based PSO approach has been used to optimize the response of variables on flexirubin production.

During optimization, the process of PSO occurred when members of the population are flown according to their flying experience, or other experiences. PSO has a population called swarms, and potential solution called particles. This particle is modified (velocity and position) at each iteration of the algorithm. The velocity and position were represented as

$$
\begin{aligned}
& \vec{X}_{i}=\left(X_{i 1}, X_{i 2}, \ldots \ldots, X_{i D}\right) \text { for } i=1,2, \ldots \ldots, N \\
& \vec{V}_{i}=\left(V_{i 1}, V_{i 2}, \ldots \ldots V_{i D}\right) \text { for } i=1,2, \ldots \ldots, N
\end{aligned}
$$

The next velocity and position of i-the particle were updated using Equations (3) and (4)

$$
\begin{aligned}
& V_{i}^{t+1}=w^{t} \cdot v_{i}^{t}+c_{1} \times r_{1} \times\left(P_{\text {best }}-X_{i}^{t}\right)+c_{2} \cdot r_{2} \times\left(G_{\text {best }}-X_{i}^{t}\right) \\
& X_{i}^{t+1}=X_{i}^{t}+V_{i}^{t+1}
\end{aligned}
$$


where $t$ is the generation of algorithm, $N$ is the number of particles, $V_{i}^{t}$ is the D-dimension velocity for $\mathrm{i}$-th particle, $X_{i}^{t}$ is the D-dimension position for $\mathrm{i}$-th particle, $C_{1}$ and $C_{2}$ are the acceleration constants, $r_{1}$ and $r_{2}$ are random variables in the range $(0,1), P_{b e s t}$ is the best position giving the best fitness value of the particle, and $G_{b e s t}$ is the best position of the best particle among all particles in the population.

In the context of this study, each particle is a potential solution and it moves in some direction with velocity, where the initial positions and velocities were randomly generated. Velocity was determined by a combination of the individual particle's best solution, the global swarm's best solution, and an inertia weight. Velocity of the particles was determined using Equation (3). Next, the positions of the particles in the solution space were obtained using Equation (4), and new feasible solutions were created. These particles continued flying until the termination criteria were met. In this approach, each particle represented a candidate solution $\left(X_{1}, X_{2}\right.$, and $\left.X_{3}\right)$ to a given problem (in this case to optimize the response of variables on flexirubin production). In PSO, the cognitive and social terms move a particle towards the best solutions based on the particle experience, and the best solution found by the swarm in the search space [25].

PSO have particles that move through the problem space by following the current optimum particles. It has a memory influence that is important to the algorithm, and only the best particle gives out information to others. The best particles and current positions allowed greater diversity and exploration over a single population (Pbest), while the momentum effect on particle movement allowed faster convergence, and more diversity in search space exploration. Although PSO particles moved randomly, which means that the variables can go outside their upper or lower limit, $X_{\min }$ and $X_{\max ^{\prime}}$, they were artificially brought back to their nearest side constraint, and it is believed to avoid velocity explosion $[9,26]$. In PSO, if the velocity becomes too high, the particles become uncontrolled and exceed search space.

Therefore, velocities are bound to maximum value, $V_{\max }$ is

If $V_{i}>V_{\max }$ then $V_{i}=V_{\max }$

If $V_{i}<-V_{\max }$ then $V_{i}=-V_{\max }$

Therefore, the value for $V_{\max }$

$V_{\max }=\frac{X_{\max }-X_{\min }}{N_{i}}$ where, $X_{\max }$ and $X_{\min }$ are the maximum and minimum values of the particles. The variables boundary for flexirubin production for this study is shown in Table 1.

Figure 3 shows a graphical representation of particle movement. $x_{1}, x_{2}$ and $x_{3}$ represent Lactose, L-tryptophan and $\mathrm{KH}_{2} \mathrm{PO}_{4}$, respectively.

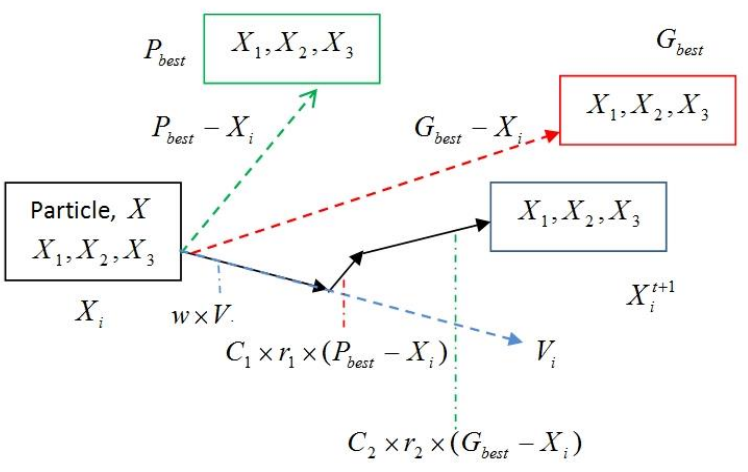

Figure 3 Graphical representation of particle movement in PSO

\subsubsection{Implementing Particle Swarm Optimization in Pigment Production}

Figure 4 shows a schematic diagram of the particle swarm algorithm implementation in flexirubin production. The left side of Figure 4 shows the pigment production step starting from bacterial culture until the end of flexirubin production, and PSO algorithm is shown on the right side of Figure 4. The most crucial part of pigment production was the fermentation process. During fermentation, the bacteria need suitable medium growth for optimum production of pigmentation. Therefore, in this process PSO was implemented to optimize the multi-variable growth medium. This study focused on three types of growth medium (nutrient broth) which are Lactose $\left(x_{1}\right)$, L-tryptophan $\left(x_{2}\right)$ and $\mathrm{KH}_{2} \mathrm{PO}_{4} \quad\left(x_{3}\right)$, respectively. This process is shown in Figure 4.

In PSO, the parameters such as the number of particles, number of generations, inertia weight, the cognitive and social components $C_{1}$ and $C_{2}$ and $r_{1}$ and $r_{2}$, play an important role in the performance of PSO [27, 28], and is also crucial to the ability of convergence. The smaller value of $w$ facilitates a local exploitation, whereas a larger value encourages global exploration [28, 29]. In this study, an inertia weight $w$ of 1 , a particle size of $50, C_{1}$ and $C_{2}$ were both 2, $r_{1}$ and $r_{2}$ were random variables in the range $(0,1)$, with the number of generations set to 50 were employed in the search criteria. In finding the optimal concentration of parameters of medium growth, the algebraic form of Equation (9) was used as fitness function while performing the optimization using PSO. 


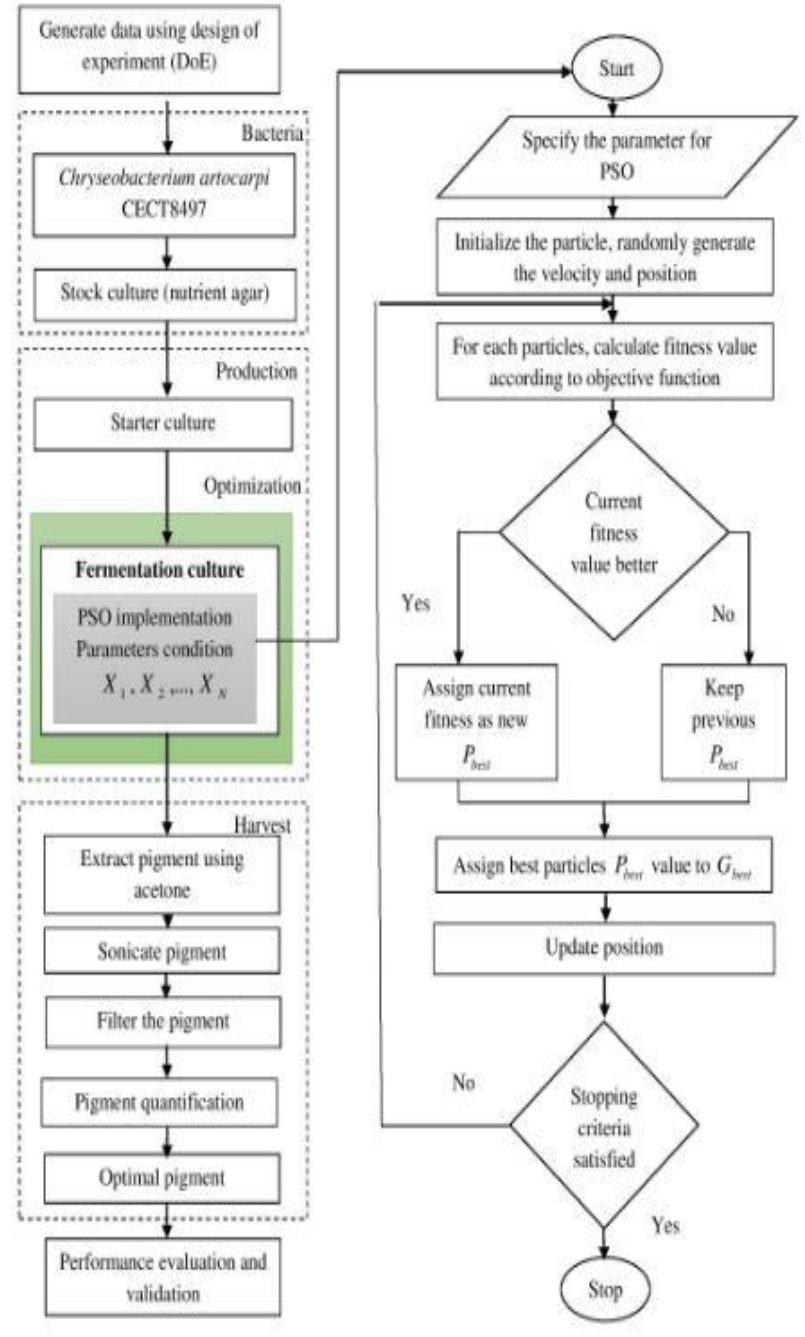

Figure 4 Schematic diagram of the PSO algorithm implementation for pigment production

\subsection{RESULTS AND DISCUSSION}

The predictive ability of statistical and artificial intelligence technique, such as response surface methodology (RSM), and particle swarm optimization (PSO) were tested to optimize the growth medium for the production of flexirubin production.

The PSO predicted and wet-lab experiments of flexirubin production are presented in Table 4. As can be seen in Table 4 (No. 6), a moderate concentration of lactose, L-tryptophan and $\mathrm{KH}_{2} \mathrm{PO}_{4}$ resulted in maximum flexirubin production, and this is verified when the optimum values of nutrient concentration for flexirubin production is $501.48 \mathrm{mg} / \mathrm{L}$, while the PSO predicted value is $487.69 \mathrm{mg} / \mathrm{L}$. Next, comparisons were made between the optimization approaches based on predictive and sensitivity analysis, as well as on the optimization efficiency of the response variables in flexirubin production.
Table 4 Experimental and predicted value (RSM \& PSO)

\begin{tabular}{|c|c|c|c|c|c|c|}
\hline \multirow[t]{2}{*}{ No } & \multicolumn{3}{|c|}{ Factors } & \multirow[t]{2}{*}{$\begin{array}{l}\text { Experimental } \\
\text { (mg/L) }\end{array}$} & \multicolumn{2}{|c|}{$\begin{array}{l}\text { Predicted } \\
(\mathrm{mg} / \mathrm{L})\end{array}$} \\
\hline & $X_{1}$ & $X_{2}$ & $X_{3}$ & & RSM & PSO \\
\hline 1 & +1 & 0 & +1 & 172.22 & 169.24 & 173.62 \\
\hline 2 & -1 & -1 & 0 & 212.98 & 224.10 & 217.93 \\
\hline 3 & 0 & -1 & +1 & 350.18 & 327.19 & 347.88 \\
\hline 4 & 0 & 0 & 0 & 480.51 & 478.14 & 487.70 \\
\hline 5 & 0 & -1 & -1 & 378.40 & 333.29 & 369.94 \\
\hline 6 & 0 & 0 & 0 & 501.48 & 498.15 & 487.70 \\
\hline 7 & +1 & -1 & 0 & 203.46 & 198.47 & 226.42 \\
\hline 8 & 0 & 0 & 0 & 483.98 & 490.43 & 487.70 \\
\hline 9 & -1 & 0 & -1 & 199.12 & 209.05 & 206.53 \\
\hline 10 & +1 & +1 & 0 & 170.39 & 181.47 & 171.80 \\
\hline 11 & +1 & 0 & -1 & 249.21 & 255.42 & 230.57 \\
\hline 12 & -1 & 0 & +1 & 151.53 & 162.63 & 180.98 \\
\hline 13 & 0 & 0 & 0 & 472.51 & 467.42 & 487.70 \\
\hline 14 & 0 & +1 & -1 & 297.54 & 280.51 & 320.65 \\
\hline 15 & 0 & 0 & 0 & 483.11 & 491.30 & 487.70 \\
\hline 16 & -1 & +1 & 0 & 194.20 & 197.02 & 179.60 \\
\hline 17 & 0 & +1 & +1 & 252.95 & 268.41 & 262.22 \\
\hline
\end{tabular}

Based on Table 4, the optimized media concentration obtained by RSM and PSO is almost similar. In the case of predictive capability, RSM predicted $498.15 \mathrm{mg} / \mathrm{L}$ while PSO predicted flexirubin yield at $487.70 \mathrm{mg} / \mathrm{L}$. The percentage error for RSM and PSO models in optimal yield production were $0.66 \%$ and $2.75 \%$, respectively.

Table 5 Statistical analysis of RSM and PSO models

\begin{tabular}{lll}
\hline Parameter & RSM & PSO \\
\hline $\begin{array}{l}\text { Correlation } \\
\text { coefficient, R2 } \\
\text { Root Mean Square }\end{array}$ & 0.9820 & 0.9894 \\
$\begin{array}{l}\text { Error (RMSE) } \\
\text { Mean Absolute }\end{array}$ & 4.9851 & 13.8108 \\
$\begin{array}{l}\text { Percentage Error } \\
\text { (MAPE) }\end{array}$ & 4.5238 \\
Maximum error & 45.11 & \\
Accuracy & 0.9612 & 29.45 \\
\hline
\end{tabular}

As shown in Table 5, RSM has a slightly better accuracy than PSO. It can be demonstrated by comparing their efficiencies. The accuracy for RSM and PSO were 0.9612 and 0.9578 , respectively. In this case, RSM has a slightly better accuracy in predicting the yield for flexirubin production than PSO. But according to Guan and Yao [30], $R^{2}$ should be at least 0.80 for the best fit of a model. From the analysis, PSO fits the experimental data with an excellent correlation compared to the RSM model. It can be seen from Table 5 that both models performed practically well, but PSO performed consistency better than RSM. In this study, the $\mathrm{R}^{2}$ value of PSO was 0.9894 , demonstrating that a good relationship existed between the independent and dependent variables compared to RSM 0.9820. ThUs, 
PSO has a slightly higher significant predictive capability than RSM.

As shown in Table 5, root mean square error (RMSE), and mean absolute percentage error (MAPE) were determined for the two techniques (RSM and PSO), where RMSE and MAPE for RSM are 14.9358 and 4.9851, respectively, while for PSO they are 13.8108 and 4.5238 , respectively. This proves that PSO is a better predictor of experimental values compared to RSM. For the validation data set, the maximum error for RSM and PSO were 45.11 and 29.45 , it can be seen that the percentage error for PSO were less than half of RSM. This again exemplifies the capability of PSO in predicting the accurate concentration of medium growth for optimum yield, compared to RSM. The statistical analysis, comparison of the predictive capability of the RSM and PSO models is shown in Table 5, while the comparative plot for RSM and PSO model prediction versus experimental yield for flexirubin production is shown in Figure 5.

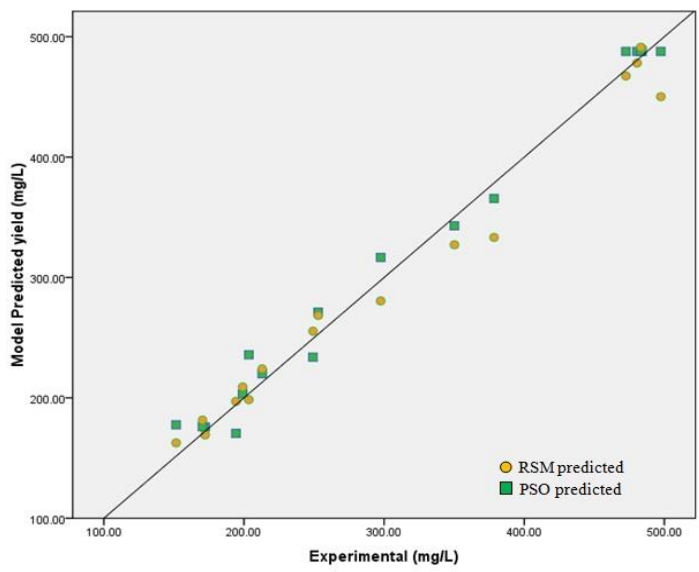

Figure 5 Scatter plot of RSM and PSO

In conclusion, the wet-lab experiment and predicted data reveal that PSO is an alternative technique for the best yield production. Indeed, PSO is an alternative tool that provides quick optimization finding the optimize response variables on flexirubin production, compared to the traditional method (RSM).

\subsection{CONCLUSION}

In this paper, artificial intelligence methodologies which are PSO algorithm is compared with wellknown RSM methods. Two optimization techniques, RSM and PSO were applied for media optimization in order to enhance the flexirubin yield by $C$. artocarpi CECT 8497'. The performance of the algorithms was evaluated by various statistical analyses, and the authenticity has been proven by wet lab experiment. Based on the experiment, PSO has advantages over the RSM technique. The PSO model demonstrated more accurate prediction than the RSM model. Thus, it can be concluded that artificial intelligence methodologies such as PSO, may present a better alternative for fermentation media optimization than the more widely used RSM method.

\section{Acknowledgement}

The authors would like to thank the Ministry of Higher Education (MOHE) for MyBrain15 scholarship and Universiti Teknologi Malaysia (UTM) for their support in Research and Development and the Soft Computing Research Group (SCRG) for the inspiration in making this study a success. This work was supported by UTM Research University Grant, Grant No. 17H62, $13 \mathrm{H} 82$ and 03G91.

\section{References}

[1] Ahmad, W. A., Yusof, N. Z., Nordin, N., Zakaria, Z. A. and Rezali, M. F. 2012. Production and Characterization of Violacein by Locally Isolated Chromobacterium Violaceum Grown in Agricultural Wastes. Applied biochemistry and biotechnology. 167(5): 1220-1234.

[2] Tuli, H. S., Chaudhary, P., Beniwal, V. and Sharma, A. K. 2015. Microbial Pigments as Natural Color Sources: Current Trends and Future Perspectives. Journal of Food Science and Technology. 52(8): 4669-4678.

[3] Reyes, F. G. R., Valim, M. F. C. F. A. and Vercesi, A. E. 1996 Effect of Organic Synthetic Food Colours on Mitochondrial Respiration. Food Additives \& Contaminants. 13(1): 5-11.

[4] Venil, C. K., Zakaria, Z. A., \& Ahmad, W. A. 2013. Bacterial Pigments and Their Applications. Process Biochemistry. 48(7): 1065-1079.

[5] Venil, C. K., Aruldass, C. A., Dufossé, L., Zakaria, Z. A. and Ahmad, W. A. 2014. Current perspective on Bacterial Pigments: Emerging Sustainable Compounds with Coloring and Biological Properties for the Industry-An Incisive Evaluation. RSC Advances. 4(74): 39523-39529.

[6] Pal, M. P., Vaidya, B. K., Desai, K. M., Joshi, R. M., Nene, S. N. and Kulkarni, B. D. 2009. Media Optimization for Biosurfactant Production by Rhodococcus Erythropolis MTCC 2794: Artificial Intelligence Versus a Statistical Approach. Journal of Industrial Microbiology \& Biotechnology. 36(5): 747-756.

[7] Wang, S. L., Yang, C. H., Liang, T. W. and Yen, Y. H. 2008. Optimization of Conditions for Protease Production by Chryseobacterium Taeanense TKU001. Bioresource Technology. 99(9): 3700-3707.

[8] Abdel-Fattah, Y. R., Saeed, H. M., Gohar, Y. M. and El-Baz, M. A. 2005. Improved Production of Pseudomonas Aeruginosa Uricase by Optimization of Process Parameters through Statistical Experimental Designs. Process Biochemistry. 40(5): 1707-1714.

[9] Eberhart, R. C., Shi, Y. and Kennedy, J. 2001. Swarm intelligence. Elsevier.

[10] Kennedy J. and Eberhart R. 1995. Particle Swarm Optimization. Proceedings of the IEEE International Conference on Neural Networks. 1942-1945.

[11] Du K. L. and Swamy M. N. S. 2016. Particle Swarm Optimization. Search and Optimization by Metaheuristics. Springer International Publishing. 153-173.

[12] Jamali, S., Alizadeh, F. and Sadeqi, S. 2016. Task Scheduling in Cloud Computing Using Particle Swarm Optimization. The Book of Extended Abstracts. 192.

[13] Prathibha, S., Latha, B. and Suamthi, G. 2017. Particle Swarm Optimization based Workflow Scheduling for Medical Applications in Cloud. Biomedical Research. 1-1. 
[14] Ryalat, M. H., Emmens, D., Hulse, M., Bell, D., AlRahamneh, Z., Laycock, S. and Fisher, M. 2016. Evaluation of Particle Swarm Optimisation for Medical Image Segmentation. International Conference on Systems Science. Springer International Publishing. 61-72.

[15] Jothi, N. 2016, December. Prediction of Generalized Anxiety Disorder Using Particle Swarm Optimization. Advances in Information and Communication Technology: Proceedings of the International Conference, ICTA 2016. Springer. 538: 480.

[16] Salehi, M. and Goorkani, M. M. 2017. Optimum Allocation of Iranian Oil and Gas Resources Using Multi-objective Linear Programming and Particle Swarm Optimization in Resistive Economy Conditions. Journal of Industrial and Systems Engineering. 10(4): 0-0.

[17] Siavashi, M. and Doranehgard, M. H. 2017. Particle Swarm Optimization of Thermal Enhanced Oil Recovery from Oilfields with Temperature Control. Applied Thermal Engineering. 123: 658-669.

[18] Soesanti, I. and Syahputra, R. 2016. Batik Production Process Optimization Using Particle Swarm Optimization Method. Journal of Theoretical and Applied Information Technology. 86(2): 272.

[19] J. Liu, X. Guan, D. Zhu and J. Sun, 2008. Optimization of the Enzymatic Pretreatment in Oat Bran Protein Extraction by Particle Swarm Optimization Algorithms for Response Surface Modeling. LWT-Food Sci. Technol. 41: 1913-1918.

[20] Hu, X., Shi, Y. and Eberhart, R. 2004. Recent Advances in Particle Swarm. IEE Congress on Evolutionary Computation. CEC2004. (1): 90-97.

[21] Venil, C. K., Nordin, N., Zakaria, Z. A. and Ahmad, W. A. 2014. Chryseobacterium Artocarpi sp. nov., Isolated from the Rhizosphere Soil of Artocarpus Integer. International Journal of Systematic and Evolutionary Microbiology. 64(9): 3153-3159.

[22] Ashlock, D. 2006. Evolutionary Computation for Modeling and Optimization. Springer Science \& Business Media.

[23] Angeline, P. J. 1998. March. Evolutionary Optimization versus Particle Swarm Optimization: Philosophy and Performance Differences. International Conference on Evolutionary Programming. Springer Berlin Heidelberg. 601610.

[24] Chauhan, M., Chauhan, R. S. and Garlapati, V. K. 2013. Modelling and Optimization Studies on a Novel Lipase Production by Staphylococcus Arlettae through Submerged Fermentation. Enzyme Research. 2013.

[25] Beheshti, Z., Shamsuddin, S. M. H. and Hasan, S. 2013. MPSO: Median-oriented Particle Swarm Optimization. Applied Mathematics and Computation. 219(11): 58175836

[26] Hassan, R., Cohanim, B., De Weck, O. and Venter, G. 2005, April. A Comparison of Particle Swarm Optimization and the Genetic Algorithm. Proceedings of the Ist AIAA
Multidisciplinary Design Optimization Specialist Conference. 18-21.

[27] Holland, J. H. 1992. Adaptation in Natural and Artificial Systems: An Introductory Analysis with Applications to Biology, Control, and Artificial Intelligence. MIT Press.

[28] Shi, Y. and Eberhart, R. C. 1998. March. Parameter Selection in Particle Swarm Optimization. International Conference on Evolutionary Programming. Springer Berlin Heidelberg. 591-600.

[29] Beheshti, Z. and Shamsuddin, S. M. 2015. Non-parametric Particle Swarm Optimization for Global Optimization. Applied Soft Computing. 28: 345-359.

[30] G. Box, W. Hunter and J. Hunter. 1958. Statistics for Experiments. New York: Wiley.

[31] Beheshti, Z. and Shamsuddin, S. M. H. 2013. A Review of Population-based Meta-Heuristic Algorithms. Int. J. Adv. Soft Comput. Appl. 5(1): 1-35.

[32] Nemati, K., Shamsuddin, S. M. and Darus, M. 2015. Solving Initial and Boundary Value Problems Using Learning Automata Particle Swarm Optimization. Engineering Optimization. 47(5): 656-673.

[33] Rini, D. P., Shamsuddin, S. M. and Yuhaniz, S. S. 2011. Particle Swarm Optimization: Technique, System and Challenges. International Journal of Computer Applications. 14(1): 19-26.

[34] Qasem, S. N., Shamsuddin, S. M., Hashim, S. Z. M., Darus, M., \& Al-Shammari, E. T. 2014. Corrigendum to Memetic Multiobjective Particle Swarm Optimization-based Radial Basis Function Network for Classification Problems. Inform. Sci. 239 (2013): 165-190, 279, 914.

[35] Pathak, L., Singh, V., Niwas, R., Osama, K., Khan, S., Haque, S. and Mishra, B. N. 2005 Artificial Intelligence versus Statistical Modeling and Optimization of Cholesterol Oxidase Production by using Streptomyces Sp. PloS One. 10(9): e0137268.

[36] Yang C. H. Cheng, K. C and Liu W-H. 2003 Optimization of Medium Composition for Production of Extracellular Amylase by Thermobifida Fusca Using a Response Surface Methodology. Food Sci Agric Chem. 5: 35-40.

[37] Wang, J., Lu D., Zhao, H., Ling, X., Jiang, B. and Ouyang, P. 2009. Application of Response Surface Methodology Optimization for the Production of Caffeic Acid from Tobacco Waste. Afr J Biotechnol. 8: 1416-1424.

[38] Baş D., and Boyac, I IH. 2007. Modeling and Optimization I: Usability of Response Surface Methodology. Journal of Food Engineering. 78: 836-845.

[39] Kim, M-J., Lim, J., Seo, J-H. and Jung, H-K. 2011 Hybrid Optimization Strategy Using Response Surface Methodology and Genetic Algorithm for Reducing Cogging Torque of SPM. Journal of Electrical Engineering \& Technology. 6: 202-207.

[40] Suhaimi, S. N., Hasan, S. and Mariyam, S. 2018. Statistical and Nature-inspired Metaheuristics Analysis on Flexirubin Production. Int. J. Advance Soft Compu. Appl. 10(2). 